\title{
UM TRATADO PARA O AMOR
}

One Treaty Toward The Love

\section{Maria José Caldeira do Amaral}

Arquivo recebido em 05 de julho de 2015 e aprovado em 13 de julho de 2015.

V. 5 - N. $9-2015$

* Pós-doutoranda em Teologia pela PUC

SP. Psicologa Clinica, Mestre e Doutora em Ciências da Religião da PUC/SP. Pesquisadora do NEMES/Nucleo de Estudos e Pesquisa em Mística e Santidade.

\section{Resumo:}

No Tratado do Amor Cortês - Tractatus de Amore - André Capelão deseja oferecer ao leitor a arte cortês de amar, a beleza do desejo erótico e a disciplina da paixão constitutiva dessa arte que é amar. O maior argumento dessa obra é efetivar o suspiro fundo que a dimensão amorosa infunde na alma do homem e da mulher aos quais foi concedida a virtude. Para esse autor, escriba da chancelaria real e talvez, não se sabe com certeza, um Ordo Sacratus, o amor é a raiz de toda cortesia, a fonte de todo bem. Nosso objetivo, então, é encontrar nessa suma amorosa construída nos enlaces da Literatura de Cavalaria Medieval, os desdobramentos essenciais dessa vida afetiva bela e virtuosa no enredo profundo do qual emerge o afeto, a fé e a contradição da experiência humana do sofrimento amoroso.

Palavras Chave: Literatura Medieval. Amor Cortês, André Capelão, virtude, desejo.

\section{Abstract}

With the treaty toward the love - Tractatus 
de Amore - André Capelão offers to the reader the courteous' art for love, the erotic desire's beauty and the suffering discipline belong this love's art is. The best reason of this literary composition is to achieve the depth sigh that the loving dimension infuses into the lovers's soul, the man and the woman wich this virtue was conceded. For this author, the royal chancery scribe and perhaps, no one knows for sure, a Sacratus Ordo, love is the root of all free, the source of all good. Our goal, then, is to find this sum loving built in interlacing of Medieval Knights literature, the essential developments of this beautiful and virtuous love life in the deep storyline which emerges affection, faith and the contradiction of the human experience of love suffering.

Key words: Medieval Literature. Courteous Love. André Capelão. Virtue. Desire.

\section{Introdução}

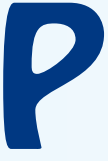

osso afirmar que um tratado sobre o amor da idade média, apesar de emitir regras de amor, advertências sobre o amar, modos e maneiras da manifestação e conduta amorosa e, até hoje, identificarmos muitas dessas maneiras por meio das quais o amor, só e somente só, poderá e ainda pode ser considerado virtuoso, parece-nos falar muito mais da virtude espiritual de nossa condição amorosa. Seria o amor cortês uma possibilidade específica de linguagem e expressão do amor humano e espiritual que surge na Europa medieval, ao mesmo tempo em que o amor a Deus é invocado nos claustros e em que o debate teológico da época se intensificava em torno da experientia caritatis, o intellectus fidei e a intelligentia amoris? A equação que se configurava, a partir dos escritos eruditos e laicos sobre conhecimento e amor, apontava para uma dinâmica equalizada entre ação e contemplação. A dinâmica entre ágape e eros está posta nos séculos XII e XIII e, a emergência dos escritos místicos ao lado da presença do conteúdo scholar se fez presente no esforço para o conhecimento de Deus a partir do amor; de acordo 
com Bernard McGinn, The loving Knowledge of God.1 Assim, falando em amor, virtude humana espiritual e conhecimento, pretendemos chegar ao fim desse artigo, desconfiados desse amar virtuoso, pois no Tratado em questão, somos informados dessa arte de amar, mas somos também alertados sobre a condenação desse amor.

Para explicar um pouco dessa nossa desconfiança em relação à virtudes, amores, conhecimento e experiências, vamos introduzir, aqui, um autor moderno, Sören Kierkegaard, para que não nos percamos no tempo medieval somente e para que possamos considerar nossas questões sobre o amor sem argumentar tão veementemente que, o amor verdadeiro, pelo menos na delimitação histórica ocidental, encontra sua expressão de maneira mais autêntica, até e inclusive a Idade Média. De lá para cá o homem passa a amar mais a sua razão do que as vicissitudes do amor. Pois bem, Kierkegaard escreve em 1847, As Obras do Amor ${ }^{2} \mathrm{e}$ disse que o amor sabe tanto quanto a experiência e a desconfiança sabem, mas não é desconfiado, porque o amor sabe que o que chamamos de experiência é propriamente uma mistura de desconfiança e amor. A experiência como desconfiança e amor é um saber do amor que não é desconfiado, porque de algum jeito esse amor que não é desconfiado sabe o que é a desconfiança, justamente por não ser desconfiado, possivelmente porque confia. A partir de Kierkegaard, podemos confiar no amor e devemos, desde agora sermos humildes, porque sabemos que a experiência de escrever um artigo acadêmico sobre o amor é uma experiência que se impõe com certa desconfiança ao leitor, e porque não, ao próprio autor.

1. Cf. McGINN, Bernard, The Flowering of Mysticism: Men and Women in the New Mysticism (1200-1350). The presence of God: A history of Western Christian Mysticism. New York: Crossroad, 2003. v. III, p. 17.

2. KIERKEGAARD, Sören A., As Obras do Amor, Petrópolis, Vozes, 2005. 


\section{O Tratactus De Amore3 e A Literatura Medieval}

Nosso objetivo, então, é encontrar nessa suma amorosa construída nos enlaces da Literatura de Cavalaria Medieval, os desdobramentos essenciais dessa vida afetiva bela e virtuosa no enredo profundo do qual emerge o afeto, a fé e a contradição da experiência humana do sofrimento amoroso.

Para isso vamos nos submeter ao convite arriscado de André Capelão, pois em sua doutrina, ele explica quase tudo sobre o amor, mas está sempre advertindo seu amigo Gautier, para quem ele dedica sua suma amorosa, sobre a experiência do amor. Ao final do Tratado, o autor deixa o leitor desconcertado, constrangido mesmo porque sintetiza para Gautier o tratado do amor cortês como um tratado completo, ou mesmo uma doutrina completa que apresenta dois pontos de vista diferentes:

Na primeira parte, quisemos responder à pergunta ingênua que a juventude escusa; recusando-nos a ceder à indolência, nos te expusemos a arte de amar, que desejavas conhecer com tanta avidez, organizando a matéria de tal modo que nada fosse omitido e adotando uma disposição perfeitamente lógica; portanto, se quisesses pôr em prática essa teoria, poderias desfrutar plenamente de todas as volúpias físicas, como mostrará a leitura atenta deste livrinho; mas nesse caso serias excluído dos bons e da amizade dos homens de mérito, causarias grande mal à tua reputação e seria bem difícil que conseguisses as honras do mundo. Na última parte deste livro, preferimos cuidar de teu interesse: é verdade que não tinhas nenhuma razão para esperar que te mostrássemos onde estaria o teu bem, e esse não era o teu desejo, mas foi por decisão própria que acrescentamos essa condenação do amor e a escrevemos para ti, criando um tratado completo. Se quiseres estudar esse

3. CAPELÃO, André, Tratado do Amor Cortês/André Capelão: introdução, tradução do latim e notas de Claude Buridant; tradução de Ivone Castilho Benedetti, São Paulo, Martins Fontes, 2000 (Coleção Gandhara). Essa obra foi publicada originalmente em latim com o título TRACTATUS DE AMORE e traduzido para o francês moderno por Claude Buridant com o título TRAITÉ De L'AMOUR CORTOUIS para Éditions Klincksieck, Paris. 
tratado com cuidado, compreender sua substância e pôr em prática os seus preceitos, descobrirás, por razão evidente, que ninguém deve desperdiçar seus dias nos prazeres do amor; se te abstiveres desses prazeres, o Rei dos Céus será mais clemente contigo, merecerás neste mundo sucesso e prosperidade, realizarás todas as ações gloriosas e concretizarás todos os desejos do teu coração; no mundo futuro, possuirás a glória e a vida eternas. ${ }^{4}$

Precisamos ficar atentos aos desdobramentos do acometimento amoroso assim como à condenação do amor e é por isso que, minimamente estaremos desenvolvendo alguns conceitos do tratado completo cotejado com a poesia e a com a ideia de alguns autores modernos sobre esse amor e seus desdobramentos hoje. Vamos começar pelo que André Capelão nos diz sobre o amor:

Amor é uma paixão natural que nasce da visão da beleza do outro sexo e da lembrança obsedante dessa beleza. Passamos a desejar, acima de tudo, estar nos braços do outro e a desejar que, nesse contato, sejam respeitados todos os movimentos do Amor. ${ }^{5}$

Essa paixão natural que nasce da visão da beleza do outro é inata, prossegue André porque ela não nasce de ação alguma, mas apenas da reflexão do espírito sobre aquilo que se vê; ${ }^{6} \mathrm{sim}$, essa paixão inata que valida a condição amorosa vem da visão e da reflexão daquele que vê, ou seja, o outro que amo passa a ser objeto de reflexão e reflexo do meu espírito. Mas essa visão há de ser descomedida, pois, se moderada, geralmente não obseca o espírito e não pode dar origem a essa paixão. ${ }^{7}$

$\mathrm{E}$ as consequencias desse reflexo do espírito sobre aquilo que se

4. CAPELÃO, André, Tratado do Amor Cortês/André Capelão: introdução, tradução do latim e notas de Claude Buridant; tradução de Ivone Castilho Benedetti, São Paulo, Martins Fontes, 2000 (Coleção Gandhara), p. 305..

5. Ibid, p.6.

6. Ibid, p.8

7. Ibid, p. 9 
vê e que dá origem a esse amor são infinitas. André descreve mesmo uma sucessão de acometimentos a partir desse olhar e desse reflexo obsedante do homem quando vê que uma mulher é digna de ser amada e convém a seu gosto. Em primeiro lugar o homem rapidamente começa a desejá-la em seu coração; depois, quanto mais pensa nela, mais se abrasa de amor por ela, até que seu pensamento seja todo invadido por esse amor, em seguida começa a imaginar suas formas, delinear seus membros e passa a tecer conjecturas sobre suas ocupações; busca ainda penetrar os segredos de seu corpo e o deseja por inteiro. Inafiançável, toda essa reflexão sobre a amada o leva a ação, pois não há como não buscar meios de estar junto a ela e, impaciente, sua inquietação permanece no fato de que

[...] nada pode ser comparado ao ato de amor, e o verdadeiro amante preferiria ser despojado de todas as suas riquezas ou ser privado de tudo que o espírito humano considera indispensável à vida a ser frustrado no amor que espera ou de que goza. Pois haverá algum outro bem sob o céu pelo qual um homem queira enfrentar tantos perigos quanto aqueles a que vemos sempre os amantes se expor de livre vontade? ${ }^{8}$

Interessante esse tratado do Amor, ele fala da coragem do verdadeiro amante em enfrentar qualquer perigo em nome do amor e, ainda diz que o verbo amar significa prender ou ser preso e usa a metáfora do anzol, pois aquele que é fisgado pelo amor deseja a qualquer custo unir dois corações ou mantê-los unidos para sempre. E, graças a esse amor, o amante torna-se elegante, confere nobreza de caráter, humildade, presteza, quaisquer que sejam esses amantes, desde que, claro, estejam engendrados nos laços do amor. ${ }^{9}$ Assim, o homem e a mulher que amam são indivíduos presos pelo amor, mas corteses e virtuosos. Estando eles sob o

\footnotetext{
8. Ibidem

9. Ibid. Cf. nota 6, p.11-12 sobre as etimologias da palavra amor, amar, afeição e seus usos na literatura medieval.
} 
efeito do amor fazem por merecê-lo como uma sabedoria de que é possível aperfeiçoarem-se elevando as qualidades indiscutíveis para prosseguir amando. Podemos pensar, rapidamente, que essa conduta posta a partir das regras são imposições e ferem a espontaneidade do amar, mas não é bem assim. $O$ amor, segundo esse escriba da chancelaria real, exige dos amantes, não propriamente um condicionamento psicológico e social, mas uma vigília intensa, um cuidado contínuo para que ele não se decline. Aquele que ama, se quiser manter o amor depois de conquistado, deve ser discreto, reservado e cuidar para que o amor não seja divulgado. Segundo o autor do tratado, assim que várias pessoas começam a conhecê-lo ele entra em declínio. Essa regra nos leva a pensar que o amor é algo impossível de ser compreendido em sua profundidade. Falar do amor que se sente para outras pessoas não é conveniente, desgasta, e, é na economia dessa anunciação que o amor se mantem e até aumenta. Inútil falar do amor que é cortesia para outrem, pois esse amor traz em si a recusa a conceitos, críticas ou elogios, por si bastar a si mesmo, por impossibilitar ideias relacionadas a essa obviedade gratuita onde não haveria causas e porquês maiores do que o desejo de mantê-lo intacto e indeclinável em si mesmo. E, após os cuidados para manter o amor, Como pode progredir o amor de que gozamos? ${ }^{10}$

Acima de tudo, diz-se que o amor aumenta quando os amantes só podem ver-se raramente e à custa de grandes dificuldades; de fato, o desejo e a paixão serão mais fortes quanto maiores forem os obstáculos a impedirem que os enamorados façam um ao outro ternas demonstrações de amor. ${ }^{11}$

10. Título do Capítulo II: "Como pode progredir o amor de que gozamos" (ibid, p.214) do Livro II "Como manter o amor" (ibid, p.209)

11. Ibid, p. 214. 
Essa ressalva ou condição reafirma o caráter atento com o qual os amantes progridem no amor de que gozam: diante desse acometimento inafiançável que é amar, e, mais uma vez, o amor cortês pede cuidado diante de um de seus princípios fundamentais que é a sabedoria implícita na preservação do desejo de desejar: o desejo de amar contem em si a desmesura, o excesso, a loucura, a obsessão e é por isso que a manutenção do desejo impõe aos amantes o paradoxo da presença e da ausência, do declarado e do interdito, da experiência e do sonho, como aguçamento da vontade. A incerteza, a dúvida, e a inquietação de quem ama são constituintes de sua evidência singular. É como se e, continuamente, o instinto estivesse melhor informado que a razão sobre essa realidade viva e indiscutível que deve ser respeitada:

Amor é, pois, feito da tensão perpétua, do desejo sempre exacerbado que é fonte de aperfeiçoamento. É o que cantam os trovadores: A separação, a ausência da senhora, a recompensa que se faz esperar: essa é a atmosfera em que se desenvolve esse sofrimento delicioso. A separação torna mais intenso o desejo amoroso e o eleva. O objeto desse desejo parece inacessível. ${ }^{12}$

O sonho também é considerado por André Capelão. Para ele, se um dos dois amantes sonhar com o outro a paixão nascerá, ou, se já existir, se fortalecerá. ${ }^{13}$ No sonho, se o autor nos permite, e como ele mesmo nos aconselha enquanto leitores, o amor se revela no desprendimento das próprias regras, no sentido exato do incompreensível, na ardência deliciosa do desejo, na profunda certeza do triunfo e na sensatez indiferente a qualquer especulação filosófica porque a recusa deliberada da lógica contem a paixão, o medo, e o perigo na dor ou no gozo ou da dor e do gozo. É na encarnação onírica do outro que nos tornamos limite e alcance de nós mesmos

12. Ibid, p. XLI Cf. nota 94 da introdução de Claude Buridan: Nada se obtém a tanto custo/ como aquilo que estou desejando;/e coisa alguma dá tanto desejo/como aquilo que não posso obter.

13. Ibid, p.214 
à revelia de nossa própria autonomia que desfalece no mistério do instante sonhado. Na cortesia do amor em sonho não existe escolha de conteúdo: o sonho é episteme de si mesmo ou o amor sonhado é amor mesmo.

Mas, interrompendo o sonho dos amantes que, a princípio, fortalece o amor, vamos elencar mais uma das principais regras do tratado do amor cortês que, segundo dizem, o próprio rei do Amor ditou pessoalmente e mandou consignar por escrito para todos os amantes. ${ }^{14}$ : O casamento não é desculpa válida para não amar, embora num outro momento, o tratado nos fala da impossibilidade do amor cortês sobreviver ao casamento nas palavras da condessa de Troyes ${ }^{15}$ :

Nem é preciso dizer que o amor conjugal está radicalmente excluído do amor cortês, e André pronuncia essa exclusão com vigor, apoiando-se na autoridade da condessa de Champagne: Dizemos e afirmamos como plenamente estabelecido que o amor não pode estender seus domínios entre os cônjuges. Porque os amantes concedem-se tudo mutuamente a título gratuito, sem serem impelidos por obrigação alguma. Os esposos, ao contrário, são obrigados por dever a obedecer às vontades recíprocas e não podem de modo algum recusar-se um ao outro. ${ }^{16}$

14. Ibid, p. 249 Cf. o capítulo VIII do Livro II: Das regras do amor.

15. Cf. ibid, p.137.

16. Ibid pp. XLI - XLII. Cf. ainda na introdução de Claude Buridan a referência em torno da autoridade conferida a Condessa Maria de Champagne. Cf. também p. XIX: Em referência ao livro de M. Lazar, Amour courtois et fin'amors dans la littérature du Xlle siécle, Paris, Klincksieck, 1954, p.268: Não é impossível que Maria de Champagne tenha sido inspiradora dessa obra, assim como fora do Lancelot de Chrétien. Visto que o "fin'amors" era ilustrado pela lírica provençal e pelo romance cortês, talvez Maria desejasse ver essa ideologia amorosa codificada num Tratado sério. Buridan concorda com esse autor sobre a datação do Tratado e sua origem: "Não é de surpreender, em todo caso, que André preste homenagem a essa condessa cuja influência foi tão marcante no mundo literário do fim do século XII; é durante esse período, ou seja, durante a regência de Maria de Champagne, que André é mencionado nos títulos de propriedade, e uma vez mesmo com o título de 'Dominus Andreas Capellanus'; portanto, ele podia ser, nessa época, o capelão pessoal da condessa, diretamente afeto a seu serviço." 
Além disso, tanto André quanto a condessa consideram o ciúme, o pai do amor e, de acordo com eles, sem ciúme, não poderá haver amor verdadeiro; é que o ciúme é também uma paixão natural da alma conciliada ao medo, que, também é um sentimento natural da alma. O amante sempre teme que seus cuidados e serviços não bastem para sustentar o amor da amada e teme que o amor dela seja menor que o dele e experimenta as torturas que sofreria se sua amada tivesse uma relação com outro amante, mesmo acreditando que isso seria impossível.

Com muita propriedade, o tratado do amor cortês afirma que existem muitos desdobramentos que contribuem para a manutenção do amor e suas afecções e, quem estiver ouvido atentamente as principais regras ditas nesse livro, certamente descobrirá sozinho outros meios para não infringir tais regras, posto que, um tratado não ousa dizer, senão numa lógica sintética, talvez precisa, mas aquém daquela que o sonho, o lamento, o gozo e a angústia sustentam a continuidade do excesso de êxtase, da identidade com a morte, do fascínio milagroso da consumação vital que nutre o desejo do bem e da virtude, mas que requer um esforço constante de superação, uma busca permanente de perfeição:

Reconheço que as boas ações realizadas merecem grandes recompensas, mas todos os homens sabem que nenhuma ação virtuosa ou cortês poderá ser realizada neste mundo se sua fonte não for o amor. O amor é origem e causa de todo bem. Se essa causa desaparecer, o efeito desaparecerá necessariamente. ${ }^{17}$

Não estamos falando, junto com André Capelão, quando se fala em amor, somente das delícias e maravilhas que estão implícitas nessa experiência humana avassaladora e impossível de ser recusada. Falamos, sim, desse suspiro fundo que traz em si mesmo a certeza da impossibilidade de não ser portador dessa paixão inata, que conhecemos como amor sapiens, no nosso tratado em foco. Mas como o amor que é uma paixão obsedante pode ser sábio? A denúncia das considerações mo-

17. Ibid, p. 30. 
dernas sobre as diferenças entre amor e paixão coloca o homem moderno a beira de uma insensatez contínua ao considerar e tentar discernir esses acometimentos livres da absoluta falta de controle que lhes são peculiares em se tratando desse amor que é paixão natural. É que, para nós, ele supera qualquer possibilidade de discernimento capaz de não identificar na alma a soberania desse acometimento incriado, inato e constituinte ativo e eterno da vida humana. O Cântico dos Cânticos, poema sapiencial da bíblia hebraica, considerado um hipertexto que influencia a literatura amorosa em todo o ocidente, até os dias de hoje, e que foi fonte de inspiração da vida monástica e da literatura religiosa sagrada, herética, erótica e vernacular em toda idade média, fala de um amor que é forte como a morte:

\section{Grava-me como selo em seu coração, Como selo em seu braço; \\ Pois o amor é forte, é como a morte! \\ Cruel como o abismo é a paixão. \\ Suas chamas são de fogo, Uma faísca de Javé!}

(Ct. Cts 8,6)

Esse amor que se coloca equalizado à morte só assim o pode ser, por meio da poesia sapiencial bíblica, porque aquela que ama (Sulamita) conhece a proximidade com a morte em seu estado "doente de amor" (Ct. Cts 2,5). No desejo rumo à plenitude, o paradoxal estado da alma em união e separação é sustentado no estado amoroso - forte como a morte e cruel como o abismo e como o fogo devorador no desequilíbrio das paixões e do desejo. ${ }^{18} \mathrm{E}$, ainda, para reforçarmos essa afirmação e fazermos o possível para que o leitor não desconfie dela, a História do Amor no Ocidente nos esclarecerá, ainda, que a combinação entre amor e morte seja aquilo que nos toca mais profundamente é um fato que estabelece à 
primeira vista o prodigioso sucesso do "romance". ${ }^{19}$ Rougemont está nos falando a respeito do início do Tristão de Bédier: ${ }^{20}$ Senhores, agrada-vos ouvir uma bela história de Amor e de Morte? ${ }^{21}$ Sobre a desconstrução da ideia de que o Tristão e Isolda seria um mito de amor o autor continua:

Não haveria mitos se fosse lícito limitar-se às certezas e exprimi-las de forma clara ou direta. Ao contrário, o mito desponta quando se torna perigoso ou impossível confessar claramente certo número de fatos sociais ou religiosos, ou de relações afetivas, que todavia se deseja conservar ou que é impossível destruir. Já não precisamos de mitos, por exemplo, para enunciar as verdades científicas: com efeito, elas são tratadas de forma inteiramente profana e, por isso mesmo, só têm a ganhar com a crítica individual. Mas precisamos de um mito para exprimir um fato obscuro e inconfessável de que a paixão está ligada à morte e leva à destruição quem quer que se entregue completamente a ela. Isso porque desejamos salvar a paixão e adoramos essa infelicidade, ao passo que as morais oficiais e a nossa razão as condenam. [...] Desse modo, determinadas realidades humanas que sentimos ou pressentimos como fundamentais estão fora do alcance da crítica. O mito exprime essas realidades, na medida em que nosso instinto exige, mas também as disfarça, na medida em que seriam ameaçadas pelo grande despertar da razão. ${ }^{22}$

Rougemont, atento às questões referentes ao estado apaixonado de expectativas em que nasce o encanto e a ilusão romanesca, pergunta: E que cumplicidades esse artifício de retórica profunda

19. ROUGEMONT, Denis de, História do Amor no Ocidente, São Paulo, Ediouro, 2003, p.23.

20. BÉDIER, Joseph, O Romance de Tristão e Isolda, 3 ed., São Paulo, Martins Fontes, 2006.

21. ROUGEMONT, Denis de, História do Amor no Ocidente, São Paulo, Ediouro, 2003, p.23.

22. Ibid, p.31. Cf nota 2: Entendendo-se aqui a razão como atividade profanadora que a razão como atividade profanadora que se exerce em detrimento do sagrado coletivo, libertando o indivíduo. Embora o racionalismo se tenha convertido em doutrina oficial, não devemos esquecer sua eficiência verdadeiramente sacrílega, anti-social e dissociadora. 
sabe despertar em nossos corações ${ }^{23}$

O enredo que emerge dessa infusão de amor na alma alcança sua máxima na poesia lírica provençal e na minnesanger ${ }^{24}$, nos séculos XI, XII e XIII de nossa história ocidental. Em quase todas as obras poéticas de língua vulgar, nos registros medievais, encontramos um amor verdadeiro e um falso amor: o rechte Liebe ou fin'amour confrontados com o unrechte ou fals'amour e Amars. Em sua maior parte os minnesänger de língua vulgar do século XII se satisfaziam em entoar alguns aspectos do amor (alegria, desgosto, angústia, mágoa, desejo carnal, louvor ás qualidades da dama cortejada, medo e fracasso do coração que ama). Por isso a idéia mais exata diante dos sentidos a serem definidos no amor cortês é difícil e arriscada, quando esses sentidos estão relacionados com outras concepções medievais do amor. ${ }^{25}$ No século XIII, o sentido do amor humano passa a ser categorizado e hierarquizado na li-

\section{Ibid, p.23.}

24. Nas últimas décadas do século XII encontramos a influência da poesia provençal francesa, especialmente na nobreza alemã; os poetas da Alemanha criaram um novo gênero da poesia provençal, a Minnesang, poesia trovadoresca, a partir da qual são desenvolvidas características próprias, dentre elas, uma seriedade integral do sentimento amoroso cuja meta é a dama única e exclusiva. A Minnesang é uma expressão que gira em torno do amor somente. Os expoentes e personagens dessa literatura são o imperador Henrique VI, Friedrich Von Hausen, Heinrich von Veldeke, Wolfram von Eschenbach, o Gottfried de Strassburg, Walther von der Vogelwide e Der Marner, dentre outros. O sentido da poesia trovadoresca alemã era o da manifestação do amor inalcançável, sem esperanças, experimentado pelo

poeta diante da beleza deslumbrante de uma dama casada de nobre linhagem. Os poetas se colocaram a serviço da assim denominada hohe Minne, o amor elevado e digno, que estava em oposição ao amor vulgar, a niedere Minne Cf. Rodolfo E. MODERN, Historia de la Literatura Alemana: Breviarios, pp. 57-90.

25. Vamos nos abster da discussão sobre a diversidade das concepções aceitas e/ou pesquisadas sobre os sentidos atribuídos ao termo amor cortês, introduzido por Gaston Paris, em 1883, dentro da literatura medieval. Cf. ROMANIA, Recuel Trimestriel Consacré a L'étude des Langues et des Littératures Romanes publié par Paul MEYER et Gaston PARIS, Tomo 110, $118^{\circ}$ Année, pp. 72 - 126. 
teratura em língua vulgar. ${ }^{26}$ Existe uma grande diferença entre a terminologia medieval e a terminologia moderna e isso favorece a ambiguidade que permanece ainda sobre as questões acerca da natureza do amor. ${ }^{27}$ Por outro lado, Octávio Paz, invocando esse fin' amours, esse amor que é quase o mesmo de André ${ }^{28}$, qualifica a aspiração do amor cortês como algo milagroso, segundo ele, um amor complementar ao erotismo filosófico platônico que não sustentava a experiência humana propriamente dita. $\mathrm{O}$ amor cortês é a experiência contida nas regras, na poesia, na lírica e nas doutrinas consteladas na experiência do ideal de vida cortês da aristocracia feudal. ${ }^{29}$ A configuração amorosa estava na literatura medieval configurada no sentimento primário que estava nas bases de uma conduta que o sublimava segundo os cânones de uma sociedade aristocrática que preservava o triunfo de valores como, a constância, a fidelidade, a dedicação desinteressada e o culto à beleza da alma.

Certamente estive em muitas grandes cortes, Mas sei que nela encontro muito mais que louvar: Mesura e sensatez e muitos outros méritos,

26. "No âmago dessa situação inextricável, como uma resultante de tantas confusões que aí deviam se enlaçar, surge a cortesia, 'religião' literária do Amor casto, da mulher idealizada, com sua 'piedade' particular, a joy d'amors, seus 'rituais' definidos, a retoricados trovadores, sua moral da homenagem e do favor, sua 'teologia' e suas disputas teológicas, seus 'iniciados', os trovadores, e seus 'crentes', o grande público culto ou não, que ouve os trovadores e faz a sua glória mundana em toda Europa. Ora, vemos essa religião do amor que enobrece ser celebrada pelos mesmos homens que persistem em considerar a sexualidade como vil; e vemos com frequência no mesmo poeta um adorador entusiasta da Dama, que ele exalta, e um depreciador da mulher que ele avilta." Cf. ROUGEMONT, Denis de, História do Amor no Ocidente, São Paulo, Ediouro, 2003, p.158.

27. Cf.ROMANIA, Recuel Trimestriel Consacré a L'étude des Langues et des Littératures Romanes publié par Paul MEYER et Gaston PARIS, Tomo 110, 118Année,1989, pp.76-77. 28. Não podemos esquecer as críticas atribuídas ao De Amore e a seu autor. Cf. a apresentação de Rued Imbach no livro Amours plurielles, publicado sob a direção de Alain BANDIOU e Barbara CASSIN, pp.18-19, na qual o autor extrai de alguns comentadores mais recentes, como Peter Dronke e Jean-Yves Tilliette, o fato de que o conteúdo da obra de André Capelão escrito entre 1182 e 1186 é uma tentativa virtuosa de imitação de todos os discursos possíveis sobre o amor, em seu tempo. BANDIOU, Alain e CASSIN, Barbara (dir.). Amours plurielles. Paris: Éditions du Seuil, 2006.

29. PAZ, Octavio, A dupla chama, amor e erotismo, São Paulo, Siciliano, 1994, p. 69-70. 
Beleza, juventude, bons feitos, gestos belos;

Nobreza Ihe ensinou Cortesia e a dotou;

De tal forma de si afastou os defeitos

Que dela nenhum bem fica ainda para dizer.

(Arnaut Daniel, 1180-1295)

Voltando a questão de Rougemont, a literatura lírica reproduz a cumplicidade profunda desperta nos corações de quem ama. Para os trovadores assim como na minnesänger a exclusividade é algo impossível de não ser e existir dentro da relação amorosa, não como requisito, mas como uma posição que já se encontra posta entre os amantes. Em Bernard de Ventadour, o desejo é tamanho por uma bela dama que todas as outras são desinteressantes.

Por causa do amor por uma nobre dama,

Aquela que me atraiu [seduziu]

E a quem eu dei em penhor meu espírito e meu coração;

Por ela, eu renunciei a todas as outras,

Pelo tanto que ela me é desejável.

(Bernard de Ventadour P.-C. 70,37) ) $^{30}$

E o tema da única dama amada é renitente como condição do verdadeiro amor... Eu vos digo, pelos santos, que o quanto eu viver nesse mundo, eu não amarei outra além de vós [..] (Cort d'Amour, século XIII, v.1224-26). E essa é uma das regras do De Amore:

Há também outra coisa no amor que merece mais que um rápido louvor: de algum modo ele ornamenta o homem com a virtude da castidade, pois aquele que é iluminado pelos raios do amor a custo pode pensar em estar nos braços de outra mulher que não seja sua bem amada, por mais bela que seja essa mulher. ${ }^{31}$

Então, damas e cavaleiros, precisamos agora sintetizar as regras do amor conclamando todos os amantes a respeitá-las escrupulosamente,

30. Tradução livre de todos os poemas aqui citados neste artigo.

31. CAPELÃO, André, Tratado Amor Cortês/André Capelão: introdução, tradução do latim e notas de Claude Buridant; tradução de Ivone Castilho Benedetti, São Paulo, Martins Fontes, 2000 (Coleção Gandhara), p. 13. 
segundo as advertências do rei do Amor que, é, também, quem as dita: ${ }^{32}$

I.O casamento não é desculpa válida para não amar.

II. Quem não tem ciúme não pode amar.

III. Ninguém pode ligar-se a dois amores ao mesmo tempo.

IV. É certo que o amor sempre aumenta ou diminui.

V. O que o amante obtém sem assentimento da amante não tem sabor algum.

VI. O homem só pode amar depois da puberdade.

VII. Depois da morte do amante, quem sobreviver deverá esperar dois anos.

VIII. Ninguém deve ser privado do objeto de seu amor sem a melhor das razões.

IX. Ninguém pode amar de verdade se a isso não for incitado pelo amor.

X. O amor sempre abandona o domicílio da avareza.

XI. Não convém amar mulher que nos envergonhe desposar.

XII. O verdadeiro amante não deseja estar em outros braços que não sejam os de sua amante.

XIII. Quando o amor é divulgado, raramente dura.

XIV. A conquista fácil torna o amor sem valor; a conquista difícil dáIhe apreço.

$X V$. Todo amante deve empalidecer em presença da amante.

XVI. Quando um amante avista de repente a mulher amada, seu coração deve começar a palpitar.

XVII. Amor novo expulsa o antigo.

XVIII. Só a virtude torna alguém digno de ser amado.

XIX. Quando diminui, o amor desaparece depressa e raramente se revigora.

$X X$. O enamorado sempre tem medo.

XXI. O verdadeiro ciúme sempre aumenta o amor.

XXII. Quando se suspeita do amante, aumentam o ciúme e a paixão.

XXIII. Quem é atormentado por cuidados de amor come menos e dorme pouco.

XXIV. Todo ato do amante tem como finalidade o pensamento da mulher amada.

XXV. O verdadeiro amante não acha bom nada daquilo que não the pareça agradar à amante.

XXVI. O amante não sabe recusar nada à amante.

XXVII. O amante nunca se sacia dos prazeres que encontra junto à mulher amada.

32. Ibid, pp. 261-262. Cf. também a nota 11, cap. VIII, Livro II: "[...] é de se notar que aqui o nosso autor, para apresentar as regras do amor a Gautier, cedeu à moda das narrativas bretãs; se lembrarmos da corte de Troyes, presidida por Marie de Champagne, estava particularmente impregnada daquela matéria da Bretanha, à qual, com grande felicidade, Chrétien conferiria conjuntura e sentido, será possível reconhecer, mais uma vez, a prova dos estreitos laços que uniam André a esse meio" 
XXVIII. A menor desconfiança leva o amante a suspeitar do pior na bem amada.

XXIX. Quem é obsessivamente atormentado pela luxúria não ama de verdade.

XXX. O verdadeiro amante é obcecado initerruptamente pela imagem da mulher amada.

XXXI. Nada impede que uma mulher seja amada por dois homens e um homem por duas mulheres.

As regras do Amor encontram-se disseminadas na lírica, na corte, na linguagem da mística feminina medieval. Mas o que seria mesmo esse tal Amor que é um rei ou possui um rei que esclarece o que se passa, como se passa e quais os desdobramentos que a dimensão amorosa inspira e suspira na alma do homem e da mulher aos quais foi concedida essa virtude, pois só a virtude torna alguém digno de ser amado e só o amor torna o homem virtuoso?

Não podemos recuar diante dessa questão, não somente pela questão em si mesma, mas porque no Livro III: Da Condenação do Amor do Tratado do Amor, o autor, alerta a Gautier:

[...] Portanto, lendo essa pequena obra não procure levar a vida dos amantes. Ao contrário, com base nos teus conhecimentos sobre o amor e instruído na maneira de seduzir as mulheres, poderás abster-te dessa arte da sedução para obteres a recompensa eterna e mereceres ser honrado com as maiores dádivas de Deus. Pois agrada mais a Deus aquele a quem foi dada a possibilidade de pecar e não a usa do que aquele a quem ela não foi dada. ${ }^{33}$

E, agora, já que o Tratado é completo, como nos avisou André, a Condenação do Amor é incisiva pelas inúmeras razões que obrigam o homem de bom senso a fugir da tirania desse acometimento insano, profano e destrutivo e a refutar suas ordens. A primeira dessas razões é que "Deus persegue com seu ódio àqueles que se dão às obras de Vênus fora dos laços do casamento ou se entregam a toda espécie de luxúria."34: 
Oh! Que dor nos invade, que amargor nos enche o coração quando deploramos incessantemente os homens as recompensas celestes para realizar os atos vergonhosos e abomináveis de Vênus. Oh! É miserável todo aquele que, pelos prazeres efêmeros da carne, desdenha as alegrias duradouras e trabalha para entregar-se às chamas da geena eterna! 35

E o autor fundamenta essa ira divina, esse pecado de amar com a história da salvação no universo cristão na qual Deus liberta a humanidade derramando seu sangue, aos homens pecadores que amam com o miserável amor terreno e assim, negam o legado eterno de que todos os homens estavam privados até que fossem resgatados pelo Rei dos Céus com seu próprio sangue. Para além da referência às ordens do antigo e novo testamento como degradação, punição com a morte, lapidação, esse amar é a ofensa mais grave que alguém pode cometer contra Deus. E, a condenação do amor, apesar de ocupar apenas 41 páginas do tratado de 306 páginas, é veemente, forte em seus argumentos ao falar dos desdobramentos nocivos, pecaminosos, destrutivos: o amor leva o amante a ultrajar o próximo, a desprezar os amigos, pois infunde ódio aos homens, impele-os ao homicídio e a outros crimes, leva-os ao ciúme odiento, a conceber o fel da raiva. Esse amar leva, ainda, à desconfiança e ao medo da contrariedade daquela que é a amada:

Quem será então suficientemente louco e estúpido para tentar obter aquilo que leva o homem a deixar-se subjugar de modo tão cruel ao poder alheio e a submeter-se em tudo à vontade de outrem? E mesmo que, às vezes, nosso amor não ofenda um amigo, por ter como alvo uma pessoa que lhe é indiferente, seus sentimentos não poderão ser retribuídos enquanto estivermos subjugados por verdadeira paixão. Porque quem é atingido pelos dardos do amor tem um só pensamento e acredita que uma só coisa lhe é útil: agradar a mulher amada e estar sempre a seu serviço, recompensando mal os serviços do amigo, que acaba negligenciado e abandonado. Deve ser considerado um miserável, que vive apenas para si e para a amante, todo aquele que, me-

35. Ibidem. 
noscabando a amizade e a ajuda de que todas as outras pessoas precisam, acredita encontrar isso no amor de uma única mulher: esse merece ser abandonado pelos amigos, e dele devem fugir todos os homens. ${ }^{36}$

O amor ainda "engendra a detestável pobreza e nos encerra na masmorra da penúria" ${ }^{37}$ com o advento da ostentação, da prodigalidade pecado mortal segundo as santas escrituras. Isso porque não havendo fortuna para sustentar esse pecado e, por isso, conduz à miséria e, na miséria o que acontece é o empenho de meios lícitos e ilícitos para saciar essa condição deplorável de pobreza:

Esse não recuará diante de nenhum crime para recuperar as riquezas que lhe permitam gozar prazeres semelhantes aos de outrora e não hesitará em cometer todos os delitos imagináveis para readquirir a opulência que possa alimentar sua paixão. Toma então cuidado e busca a causa antes de expor-te a consequência que não seria fácil evitar. ${ }^{38}$

A condição anímica humana degrada, piora, desintegra diante desse amar. $\mathrm{E}$ a condenação prossegue de maneira contundente e toma a lascívia, a volúpia e a luxúria como causas da indolência, da preguiça, da criminalidade, do roubo, do adultério, do homicídio. O amor destrói os matrimônios, não sustenta a sabedoria, debilita a saúde:

A sabedoria é então impotente para dominar os impulsos da luxúria e refrear os atos funestos que serão cometidos. Chega-se a dizer que os sábios se perdem mais facilmente nos descaminhos do amor e que se entregam com mais ardor aos prazeres da carne do que as pessoas que tem menos domínio de si. No entanto, depois de sucumbirem ao pecado do amor, de modo geral passam a desprezar os erros da luxúria muito mais que os outros em cujo socorro só acudiu a medíocre sensatez. ${ }^{39}$

36. Ibid., pp. 272-273.

37. Ibid., p. 273.

38. Ibid. p. 274.

39. Ibid. p. 287. 
A condição da mulher, a amada, é a mais falsa e a mais inconstante e nessa falsidade e inconstância André não deixa escapar em suas advertências a natureza da mulher como gananciosa e contaminada pelo pecado da avareza e cupidez:

As mulheres, aliás, não são apenas avaras por natureza, mas também são curiosas e falam mal das outras mulheres; são vorazes, escravas do próprio ventre, volúveis, inconstantes no que falam, desobedientes, rebeldes às proibições; são maculadas pelo pecado do orgulho e cobiçam a vanglória; são mentirosas, dissolutas, tagarelas, não respeitam segredos; são luxuriosas ao extremo, dadas a todos os vícios e não têm afeição verdadeira pelos homens. ${ }^{40}$

As mulheres são invejosas, a beleza das outras mulheres as mata de ciúmes e lhes destrói a felicidade ${ }^{41}$, são maledicentes, têm a língua pérfida, denigrem a reputação dos bons, apegadas a seus próprios louvores, inconstantes, infiéis, hipócritas, presas à vanglória, muitas delas ébrias.

Os pecados, venais, originais e mortais estão todos ligados ao amor cortês. Os dez mandamentos estão violados por essa arte de amar. A idolatria, o falso testemunho, o homicídio, a soberba, o orgulho, a luxúria, a ira suplantam e assombram aqueles que amam. $E$, finalmente, no nosso tratado em questão, está posta a advertência fundamental:

Escolhe, pois, Gautier, a doutrina salutar que te propomos e esquece de vez todas as vaidades do mundo, para que, quando o Esposo celeste vier celebrar as núpcias sublimes e o clamor se elevar na noite, estejas pronto para correr perante Ele com as lâmpadas cheias de azeite e entrar com Ele no casamento divino; para que não precises então procurar à pressa com o que encher tuas lâmpadas e acha-lo tarde demais, chegando à morada do Esposo quando as portas já estiverem fechadas e se fizer ouvir a voz da vergonha. [...] que os prazeres do mundo não te façam jazer no sono do peca- 
do, confiando demais na juventude do teu corpo e certo de que o Esposo virá mais tarde, ao passo que, como nos adverte sua voz, não conhecemos o dia nem a hora de sua chegada. ${ }^{42}$

Nos enlaces do amor, atingidos por seus dardos não terá o ser humano a experiência da lucidez da alma, da pureza, da escolha atual e salutar de encontrar a deidade, a vida sem vaidades, a castidade. $\mathrm{O}$ amante cortês, ao contrário, está distante da experiência da vida espiritual completa, do amor a Deus, do alcance do eterno e da eternidade.

\section{Considerações Finais}

Um Tratado para o amor é um tratado completo. Ao mesmo tempo em que ele contém a virtude espiritual da nossa condição amorosa, sendo ele mesmo um estado natural da alma, posto que o medo, o ciúme, a inveja e a desconfiança também complementam a ontologia anímica, a realidade humana fundamental do Amar está fora da possibilidade da crítica. Podemos confiar no Amor Cortês? Ou melhor, o que nos resta sentir ou pensar diante de um acometimento inafiançável que o próprio autor descreve com tamanha sintonia à linguagem medieval de sentido lírico provençal, místico e porque não, psicológico? Porque preferimos a dor ao nada? Se o outro que amo como objeto de reflexão é reflexo do meu espírito, não poderei recusá-lo, mesmo diante de tanta desconfiança. Os amantes estão condenados e o amor também poderia ser, então, se comparado ao ponto de vista de alguns

42. Ibid. p.306. 
autores modernos ${ }^{43}$, a razão de todo sofrimento da alma. Esses autores, apesar de filhos do iluminismo, esse controlador de todas as forças dionisíacas, que colocam o desejo como o mal estar da civilização, não desprezam as advertências de André Capelão a Gautier e a nós leitores. Sob o ponto de vista da Psicologia, por exemplo, encontramos em Eros e Pathos de Aldo Carotenuto, a presença da maldade que a carga amorosa traz à tona, à consciência. Carotenuto aponta para o amor como subversão da alma. Segundo ele, a maldade (sentimentos e conteúdos inconscientes) que a carga amorosa trás à superfície aparece, com violência, e, aqueles que a vivenciam e a levam até as últimas consequências, não suportam psicologicamente a epifania do mal interior. A morte dos amantes se constela, então, como elemento necessário para recompor a ordem subvertida pela força destrutiva do amor. A morte é a conclusão natural do amor, não por vontade dos amantes, mas porque o mundo não pode aceitar a carga subversiva que esse sentimento ou, melhor dizendo, esse acometimento autômato, intenso, lânguido e avassalador, provoca. $O$ amor rompe os diques da existência e subverte a ordem constituída e, por isso deve ser aniquilado. ${ }^{44}$ As leis não podem proibir os amantes de se

43. Aqui Rougemont nos auxilia também: Os modernos, com efeito, a partir de Rosseau, imaginam que existe uma espécie de natureza normal à qual a cultura e a religião teriam acrescentado seus falsos problemas... Essa tocante ilusão pode ajuda-los a viver, mas não a compreender suas vidas. Isso porque todos nós, assim como somos, sem saber levamos nossas vidas de civilizados numa confusão insensata de religiões jamais completamente mortas e poucas vezes inteiramente compreendidas e praticadas; de morais outrora exclusivas, mas que se superpõem no cenário de nossas condutas elementares; de complexos muito ativos, embora inaugurados, e de instintos herdados muito menosde qualquer natureza animal do que de costumes totalmente esquecidos que se tornaram traços ou cicatrizes mentais, completamente inconscientes e, portanto, facilmente confundidas com o instinto. Tais costumes foram ora artifícios cruéis, ora rituais sagrados ou gestos mágicos, e por vezes também disciplinas profundas, elaboradas por místicas longínquas, simultaneamente no tempo e no espaço. Cf. DE ROUGEMONT, Denis. O Amor e o Ocidente. Segunda edição. Lisboa: Ed. Vega, 1999, p. 160.

44. CAROTENUTO, Aldo, Eros e Pathos, São Paulo, Paulus, 1994, p. 24. 
enamoraram, nem a condenação do tratado, pois André Capelão, ao condenar o amor e justificar com clareza e realidade esses desdobramentos nefastos, dolorosos e assertivos do amar cortesmente diz também com exímia propriedade: Quanto aos sofrimentos a que são submetidos os amantes em vida, falei muito já a respeito, mas não acredito que alguém os possa conhecer perfeitamente se não for instruído pela experiência. ${ }^{45} \mathrm{E}$ para o nosso eros e pathos moderno é a própria sociedade que deixa morrer quem ousou transgredir levando uma centelha divina para o sulco sempre igual e cinzento da existência e essa não deve ser uma conclusão negativa sobre o amor, mas um convite à reflexão:

Devemos dar-nos conta de que somos dilacerados por uma profunda ambivalência: de um lado desejamos, anelamos o amor; de outro, nós o repelimos porque temos medo dele, e nos refugiamos no cotidiano, nas relações mais chãs e banais. Devemos dar-nos conta desta verdade amarga e terrível: o mundo não quer o amor e não o sabe. ${ }^{46}$

Advertidos por Soren Kierkegaard, desde o início da análise do $D e$ amore seguimos ainda a reflexão da psicologia moderna que vê aqueles que ousaram transgredir levando a centelha divina para a existência arriscarem-se ou a morte ou às relações chãs, prosseguimos na experiência que é uma mistura de desconfiança e amor, com o apoio de André Capelão. Mas ao ouvir a voz do amor clamando o desejo e a loucura, a delícia e o tormento, o melhor que temos a fazer é invocar Chrétien de Troyes:

De todos os males, o meu difere; ele me agrada; regozijo-me com ele; meu mal é o que desejo e minha dor é meu bem estar. não vejo, portanto,de que me queixar, pois meu mal advém de minha vontade; é meu querer que se torna meu mal; tenho tanto gosto em querer assim que sofro prazerosamente, e há tanta alegria em minha dor que me delicio com a minha doença.

45. CAPELÃO, André, Tratado do Amor Cortês/São Paulo, Martins Fontes, 2000, p.275.

46. CAROTENUTO, Aldo, Eros e Pathos, São Paulo, Paulus, 1994, p.24. 


\section{Referências Bibliográficas}

AMARAL, Maria José Caldeira do, Imagens de Plenitude na Simbologia do Cântico dos Cânticos, São Paulo, Educ/Fapesp, 2009

BANDIOU, Alain e CASSIN, Barbara (dir.). Amours plurielles. Paris: Éditions du Seuil, 2006.

BÉDIER, Joseph, O Romance de Tristão e Isolda, 3 ed., São Paulo, Martins Fontes, 2006.

CAPELÃO, André, Tratado Amor Cortês/André Capelão: introdução, tradução do latim e notas de Claude Buridant; tradução de Ivone Castilho Benedetti, São Paulo, Martins Fontes, 2000 (Coleção Gandhara)

CAROTENUTO, Aldo, Eros e Pathos, São Paulo, Paulus, 1994

DE ROUGEMONT, Denis. O Amor e o Ocidente. Segunda edição. Lisboa: Ed. Vega, 1999.

KIERKEGAARD, Sören. As obras do amor: algumas considerações cristãs em forma de discursos. Trad. Álvaro Luiz Montenegro Valls e revisão de Else Hagelund. Bragança Paulista: Editora Universitária São Fransisco/ Petrópolis: Vozes, 2005.

LAZAR, M., Amour courtois et fin'amors dans la littérature du XIle siécle, Paris, Klincksieck, 1954.

McGINN, Bernard. The foundations of mysticism. The presence of God: A history of Western Christian Mysticism. New York: Crossroad, 2003. v. I.

. The Flowering of Mysticism: Men and Women in the New Mysticism (1200-1350). The presence of God: A history of Western Christian Mysticism. New York: Crossroad, 2003. v. III.

MODERN, Rodolfo E. História de La Literatura Alemana - Breviários. México: Fondo de Cultura Económica, 1995.

PAZ, Octavio, A DUPLA CHAMA, AMOR E EROTISMO, São Paulo, Siciliano, 1994.

ROMANIA, Recuel Trimestriel Consacré a L'étude des Langues et des Littératures Romanes, publié par Paul MEYER et Gaston PARIS, Tomo 110, 118응 Année. Paris: F. Vieweg, Libraire-Éditeur,1989. 